\section{Pandangan Hidup Masyarakat Sasak dalam Leksikon Nama Sèsèkan: Sebuah Tinjauan Linguistik Antropologi}

Ilfat Isroi Nirwani

Fakultas IImu Budaya, Universitas Gadjah Mada

Surel: ilfat.isroi.nirwani@mail.ugm.ac.id

\title{
INTISARI
}

Penelitian ini berisi leksikon sèsèkan dengan teori linguistik antropologi Duranti dan Wierzbecka Penamaan leksikon sèsèkan tidak tanpa sengaja, tetapi ada makna dan faktor-faktor tertentu yang terkandung di dalamnya. Makna dan faktor budaya tertentu itulah yang ingin diketahui oleh penulis. Penelitian ini berusaha menjawab pertanyaan, bagaimana pandangan masyarakat Sasak terhadap sèsèkan berdasarkan leksikon-leksikon sèsèkan tersebut. Penggunaan teori linguistik antropologi untuk mengkaji leksikon sesekan diasumsikan sebagai pilihan yang tepat karena dapat mengungkapkan budaya masyarakat Sasak. Metode dalam penelitian ini terbagi menjadi tiga tahap, yaitu persiapan penelitian, pengumpulan data, dan analisis data. Data penelitian diperoleh dari studi lapangan dan studi pustaka. Analisis data dengan metode deskriptif kualitatif. Hasil analisis data disajikan secara informal. Dalam penelitian ini ditemukan bahwa sèsèkan memiliki hubungan yang erat dengan kehidupan masyarakat Sasak. Hal ini terbukti dari penyebutan leksikon-leksikon nama sèsèkan dengan sangat mendetail sesuai fungsi dan makna yang terkandung di dalamnya. Leksikon-leksikon sèsèkan memberi gambaran tentang kehidupan sosial, agama, dan budaya masyarakat Sasak. Leksikon sèsèkan dalam pandangan masyarakat memiliki fungsi budaya, keagamaan, dan sosial yang terklasifikasi sebagai benda pakai sehari-hari, perlengkapan upacara, dan benda magis.

Kata kunci: sèsèkan, leksikon, linguistik antropologi, pandangan hidup

\section{PENDAHULUAN}

Bahasa adalah alat intelektual paling fleksibel dan hebat yang dikembangkan oleh manusia. Salah satu dari sekian banyak fungsinya adalah kemampuan untuk merefleksikan dunia, termasuk dirinya itu sendiri (Duranti, 1997:7). Bahasa sering disebut sebagai produk budaya atau produk sosial. Sebagai produk budaya, bahasa merupakan wadah interaksi sosial yang bertujuan mengungkapkan ide, gagasan, maksud, dan tujuan tertentu. Perkembangan budaya mempengaruhi perkembangan bahasa, salah satunya berupa leksikon atau istilah dalam budaya tertentu.

Penggunaan bahasa -dalam hal ini leksikon- terealisasi dalam berbagai aspek kehidupan masyarakat, misalnya leksikon dalam kegiatan perbatikan pada masyarakat Jawa, leksikon dalam kegiatan pertenunan pada masyarakat Kalimantan, Sulawesi, NTB, dan NTT. Batik dan tenun merupakan produk budaya sehari-hari masyarakat. Pada produk ini sama-sama merupakan produk yang digunakan untuk pemenuhan kebutuhan sandang masyarakat. 
Meskipun Kalimantan, Sulawesi, NTB, dan NTT sama-sama memiliki kain tenun, tetapi dalam proses pembuatan, cara pembuatan, penyebutan produk-produk, dan lain-lain berbeda. Tergantung bagaimana pola pikir masyarakat penghasilnya. Dalam penelitian ini akan dibahas tentang leksikon sèsèkan (kain tenun) di Lombok, NTB oleh masyarakat Sasak.

Suku Sasak mengenal kegiatan menenun kain untuk keperluan sehari-hari. Kegiatan menenun ini disebut nyesek dan kain tenun disebut sèsèkan. Sèsèkan yang dihasilkan masyarakat Sasak memiliki varian yang beragam. Ragam itu juga memiliki kandungan makna serta nilai estetika yang tinggi. Sèsèkan juga dipercaya memiliki nilai yang sakral dan tidak sembarang orang bisa mengenakannya. Untuk itulah, sèsèkan memiliki leksikon-leksikon nama tertentu yang menyimpan pandangan masyarakat Sasak terhadapnya. Leksikon-leksikon tersebut muncul bukan tanpa sengaja, tetapi ada makna-makna tertentu yang terkandung di dalamnya. Maknamakna tertentu itulah yang ingin diketahui oleh penulis. Dalam penelitian ini dibatasi pada leksikon nama-nama sèsèkan yang dihasilkan dengan teknik pelekat dan teknik songket. Pada penelitian ini, penulis mencoba menguraikan penggunaan leksikon sèsèkan untuk mengungkap kearifan budaya yang dimiliki oleh masyarakat Sasak. Misalnya penamaan sèsèkan yang diambil dari nama benda langit, yaitu bintang dan bulan. Bintang dan bulan adalah simbol sèsèkan untuk kaum perempuan dan muda-mudi yang menjalin hubungan, contohnya bintang remawe, bintang empat, bulan bekurung, dan bulan begantong.

Masalah yang ingin diungkapkan dalam penelitian ini, yaitu bagaimana pandangan masyarakat Sasak terhadap sèsèkan berdasarkan leksikon-leksikon sèsèkan tersebut. Dengan berusaha menjelaskan masalah tersebut diharapkan penelitian ini dapat menyumbangkan pandangan bagi pengembangan ilmu linguistik, khususnya dalam kajian linguistik antropologi dalam mengungkapkan kebudayaan suatu masyarakat yang tercermin dalam bahasanya.

Terdapat beberapa penelitian yang telah dilakukan tentang leksikon menggunakan kajian linguistik antropologi atau etnolinguistik dengan berbagai objek penelitian yang berbeda-beda, diantaranya penelitian yang dilakukan oleh Sari (2015) berjudul "Leksikon Hantu dalam Bahasa Indonesia (Tinjauan Linguistik Antropologis)". Penelitian ini berusaha menemukan leksikon hantu yang terdapat dalam bahasa Indonesia, bentuk klasifikasinya, dan gambaran kognisi orang Indonesia dalam memikirkan hantu. Sari menjelaskan bahwa dalam perspektif budaya, hantu lebih dimaknai sebagai sesuatu makhluk yang bernilai 'menakutkan'. Sementara, leksikon hantu atau makhluk halus yang dikenal dalam agama, seperti setan, iblis, dan lain-lain, berarti sebagai makhluk jahat yang menjerumuskan mansuia untuk melanggar perintah Tuhan. Kemudian, penelitian yang dilakukan oleh Fatehah (2008) berjudul "Leksikon perbatikan di Pekalongan: Kajian Etnolinguistik". Penelitian ini memaparkan klasifikasi-klasifikasi leksikon kain batik masyarakat Pekalongan di daerah pesisir berdasarkan beberapa kategori. Selain 
mendeskripsikan klasifikasi tersebut, Fatehah juga menjelaskan fungsi leksikon-leksikon perbatikan dalam mencerminkan budaya dan pola pikir masyarakatnya. Cerminan budaya itu berupa ditemukannya identitas sosial pembagian kerja berdasarkan gender, identitas sosial berdasarkan strata ekonomi, identitas keagamaan, dan sebagai bingkai budaya pesisir.

Penelitian ini dimulai dengan penelusuran dan telaah pustaka yang berhubungan dengan objek penelitian. Langkah ini merupakan langkah untuk mengumpulkan informasi yang relevan untuk penelitian dan menghindari adanya duplikasi penelitian. Selain itu, dilakukan pula wawancara terhadap beberapa informan. Selanjutnya, analisis data dilaksanakan dengan cara mengindentifkasi dan mengklasifikasi data penelitian berdasarkan pada kelompok-kelompok tertentu lalu menjelaskannya. Analisis data juga berdasarkan instrospektif peneliti sebagai masyarakat Sasak. Hasil analisis dilakukan secara informal.

Penelitian ini berangkat dari teori linguistik antropologi yang diungkapkan oleh Duranti dan Wierzbecka. Duranti (1997:5\&21) menyatakan bahwa linguistik antropologi berawal dari asumsi teoritis bahwa kata-kata penting yang ditemukan dari temuan empiris merupakan tanda-tanda linguistik sebagai representasi dunia dan hubungan kata-kata itu dengan dunia tidak pernah netral. Kata-kata itu terus-menerus digunakan untuk membangun kedekatan budaya dan perbedaan budaya. Oleh karena itu, bahasa sering diartikan sebagai alat penyimpan kebudayaan.

Dengan menggunakan bahasa, manusia mengidentifikasi benda-benda, atau menggunakannya sebagai alat berpikir, atau menyediakan catatan, berupa kode simbol untuk menggambarkan dunia di sekitar mereka (Sibarani, 2004:38). Wierzbicka (1997: 1-3) mengungkapkan bahwa ada hubungan yang sangat erat antara kehidupan masyarakat dan leksikon bahasa yang diucapkannya. Hal ini berlaku dalam ukuran yang sama terhadap aspek luar dan dalam kehidupan. Contoh yang jelas terlihat adalah makanan. Wierzbicka lebih lanjut mengungkapkan bahwa bukanlah sebuah kebetulan, misalnya Polandia memiliki kata-kata khusus untuk rebusan kubis (bigos), sup bit (barzcz), dan selai plum (powidta), yang tidak ada dalam bahasa Inggris; atau misalnya dalam bahasa Inggris terdapat kata khusus untuk selai oranye (mermalade), dan kata Jepang untuk minuman beralkohol yang kuat yang terbuat dari beras (sake). Jelas, katakata seperti itu bisa memberi tahu kita sesuatu tentang kebiasaan makan atau minum dari orang-orang yang bersangkutan. Tidak hanya leksikon tertentu pada makanan, juga dalam bidang lain, seperti yang telah diuraikan pada bagian latar belakang, misalnya dalam penamaan berbagai hasil karya sandang, dalam bahasa Jawa terdapat batik, di Sumatera Utara dikenal ulos, di Kalimantan dikenal dengan doyo, di Sulawesi ada donggala, dan di Lombok ada sèsèkan. Berikut diuraikan cara pandang masyarakat Sasak terhadap sèsèkan melalui leksikon nama sèsèkan. 


\section{HASIL DAN PEMBAHASAN}

\section{Pandangan Hidup Masyarakat Sasak yang Tercermin dalam Leksikon Nama Sèsèkan}

Manfaat sèsèkan bagi masyarakat Sasak cukup besar. Keberadaannya terwujud karena kebutuhan masyarakat Sasak akan sandang dan pada saat ini sèsèkan merupakan salah satu kebutuhan sandang yang berbentuk tradisional. Kebutuhan tersebut telah memunculkan manfaat-manfaat tersendiri bagi masyarakat Sasak. Karena manfaatnya tersebut, tidaklah mengherankan jika dalam berinteraksi dengan dunia sèsèkan masyarakat Sasak memilah-milah atau mengklasifikasikannya berdasarkan pada manfaatnya (Suhandano, 2004:173). Pengklasifikasian sèsèkan berdasarkan manfaatnya ini disebut klasifikasi fungsional.

Klasifikasi fungsional tersebut berkaitan dengan manfaat kain tenun bagi suatu masyarakat. Manfaat tersebut, misalnya dalam bahasa Bambara di Afrika Barat yang dituturkan oleh suku Mali, salah satunya mengklasifikasikan kain tenun yang digunakan sebagai benda upacara, ketika upacara memperingati bahasa, mereka memakai kain yang disebut "kain kata" atau word cloths (Yuko, 2013:101-102). Pemberian nama tersebut berhubungan dengan manfaat kain itu bagi suku Mali. Klasifikasi fungsional nama sèsèkan juga dilakukan dengan memeriksa bahasa Sasak, dalam hal ini leksikon nama sèsèkan. Dengan mencermati leksikon nama sèsèkan dalam bahasa Sasak ditemukan pandangan budaya masyarakat penuturnya terhadap sèsèkan. Dalam konteks ini, dikemukakan bagaimana masyarakat memandang sèsèkan melalui kemunculan leksikon nama sèsèkan tersebut kemudian memanfaatkannya. Pemanfaatan sèsèkan diklasifikasikan ke dalam 3 klasifikasi. Pertama, sèsèkan untuk benda pakai sehari-hari; kedua, sèsèkan untuk perlengkapan upacara; ketiga, sèsèkan sebagai benda magis.

\section{a. Benda Pakai Sehari-Hari}

Pentingnya sèsèkan bagi masyarakat Sasak telah merealisasikan manfaat yang melekat pada sèsèkan itu sendiri. Realisasi ini dapat dilihat dari leksikon nama sèsèkan yang muncul seiring terciptanya berbagai sèsèkan. Realisasi pertama, yaitu penggunaan sèsèkan dalam aktivitas sehari-hari. Sebagai benda pakai sehari-hari, sèsèkan dibagi lagi menjadi beberapa klasifikasi, yaitu sèsèkan sebagai penanda aktivitas sosial dan lingkungan alam, sèsèkan sebagai penanda status sosial, sèsèkan sebagai penanda religiusitas, sèsèkan sebagai penanda kepemilikan, dan sèsèkan sebagai penanda selera pasar. Berikut diuraikan masing-masing klasifikasi tersebut.

Penanda Aktivitas Sosial dan Lingkungan Alam

\section{1) Bêbêt Antêng dan Rêjasa}

Bêbêt antêng juga sering disebut cabuk antêng merupakan kain yang digunakan sebagai ikat pinggang oleh perempuan sedangkan rêjasa digunakan oleh laki-laki. Pada zaman dahulu, 
penggunaan bêbêt antêng dan rêjasa dipadukan dengan kéré berêng atau kêmbang komak. Fungsi kain ini untuk menjaga agar kéré berêng dan kêmbang komak tetap teguh membalut tubuh pemakainya. Pada masa sekarang, bêbêt antêng dan rêjasa juga dapat digunakan oleh pemangku adat dalam upacara potong rambut bayi (bêkuris) dan sunat (nyunatang) yang dipadukan dengan kéré bérêng.

\section{2) Kéré Berêng dan Kêmbang Komak}

Kéré berêng dan kêmbang komak merupakan kain yang digunakan oleh masyarakat Sasak sebagai pakaian sehari-hari, terutama ketika aktivitas pertanian. Pemilihan warna hitam pada kedua kain ini bukan tanpa alasan. Pada zaman dahulu masyarakat Sasak mengenal warna hitam dari warna lumpur. Oleh karena itu, masyarakat Sasak memberi warna hitam pada kéré berêng dan kêmbang komak dengan merendam bahan dasar kain yang sudah berbentuk benang ke dalam lumpur selama 6 bulan-1 tahun, tergantung kepekatan warna yang ingin dihasilkan. Selain untuk memperoleh warna hitam, perendaman ini juga bertujuan untuk menguatkan serat-serat benang sehingga kain tidak mudah rusak. Pada zaman dahulu, di Lombok sumber air bersih masih sulit ditemukan sehingga untuk menghemat air masyarakat Sasak jarang mencuci pakaian. Hal itu juga menjadi alasan kéré bérêng dan kêmbang komak diberi warna hitam. Jadi, karena berwarna hitam, kain-kain tersebut tidak begitu terlihat kotor. Masyarakat Sasak dapat menyamarkan kekotoran yang ada pada kainkain tersebut apabila berwarna hitam. Setelah berkembangnya agama Islam di Lombok, warna hitam diberi makna 'kembali'. Artinya, sesibuk apa pun manusia dengan aktivitas di dunia mereka harus tetap mengingat asal mereka. Kain ini diharapkan dapat mengingatkan masyarakat untuk beribadah kepada Tuhan. Kain kéré bérêng dan kêmbang komakjuga sering digunakan sebagai selimut. Apabila digunakan ketika musim dingin, kéré bérêng dan kêmbang komak akan menjadi hangat dan ketika digunakan pada musim panas akan menjadi sejuk.

Khusus pada kain kêmbang komak yang berasal dari kata kêmbang dan komak. Dalam bahasa Indonesia, kêmbang berarti 'bunga' dan komak berarti 'sayuran seperti kedelai' (Latin: Lablab purpureus). Penamaan kêmbang komak merujuk istilah yang digunakan oleh masyarakat Sasak untuk menyebut pergantian musim panas ke musim dingin, yaitu 'telih kêmbang komak'. Sayuran komak biasanya mulai berbunga ketika musim dingin datang. Oleh karena itulah, masyarakat Sasak menamai perpindahan musim ini dengan nama 'têlih kêmbang komak'. Pada saat perpindahan musim ini, udara di Lombok cukup dingin. Pada musim inilah biasanya kain kêmbang komak digunakan, terutama oleh kaum laki-laki saat pergi ke sawah agar tidak masuk angin terkena udara dingin atau sekedar dililitkan sebagai penghangat badan di rumah. 


\section{3) Kèkèr dan Kêdéa}

Penamaan sèsèkan juga dapat menggambarkan hal-hal yang banyak terdapat dalam lingkungan sekitar masyarakat Sasak. Kain-kain tersebut, misalnya kèkèr dan bêlincêk yang diambil dari nama binatang. Kèkèr berarti 'undur-undur' dalam bahasa Indonesia. Diambilnya nama kèkèr sebagai nama sèsèkan ternyata menunjukkan bahwa binatang kèkèr banyak ditemukan di Lombok, biasanya, mereka berada di dalam tanah gembur pinggiran tembok rumah yang terbuat dari batubata merah dan di bawah dangau sawah. Untuk mengetahui lubang sebagai rumah yang dibuat oleh binatang ini cukup mudah. Lubang-lubang yang ditinggali binatang ini membentuk cekungan ke dalam tanah dan tanah penutup lubangnya sangat halus. Anak-anak suku Sasak suka berburu binatang kecil ini untuk dijadikan mainan. Mereka berburu dengan cara memancing kèkèr dengan serat batang pohon pisang. Ketika kèkèr berhasil dipancing, mereka menempatkan kèkèr pada suatu wadah yang telah diberi tanah agar kèkèr dapat membuat rumah di dalam wadah tersebut. Ketika muncul lekukan pada wadah tersebut, anak-anak akan merasa puas karena mereka merasa telah berhasil membuat kèkèr nyaman di rumah barunya.

Sama halnya dengan kèkèr, kain kêdéa juga diambil dari nama binatang yang dekat dengan masyarakat Sasak. Kata Kêdéa berarti 'capung' dalam bahasa Indonesia. Capung merupakan binatang yang banyak ditemui di Lombok. Ketika sore hari, binatang ini suka muncul berbondong-bondong di sawah atau di tanah lapang. Anak-anak suku Sasak banyak yang bermain di sore hari. Salah satu aktivitas yang mereka lakukan adalah menangkap kêdéa. Menangkap kêdéa merupakan permainan yang cukup menarik karena binatang ini tidak mudah ditangkap. Ada kepuasan tersendiri ketika berhasil menangkap kêdéa. Ada sebuah lagu yang sering dinyanyikan oleh anak-anak ketika hendak menangkap kêdéa. Lagu ini mereka peroleh dari para orangtua. Konon jika menyanyi lagu ini, kêdéa akan lebih mudah ditangkap. Lagu itu berjudul Dea Dampong. Lirik lagu tersebut adalah rinjoa-rinjoa bêbatang anggit-anggit//bi milu ke bêdéa bi mangan jangan rarit//dea-dea dampong, déa-déa dampong//mênéjangan bi kakên iyêl/bêr bêr nê pêngakên mpak baturnê.

Dinamainya sèsèkan dengan nama kèkèr dan kêdéa merepresentasikan dekatnya binatang tersebut dalam kehidupan masyarakat Sasak. Dalam hali ini, sèsèkan merupakan sarana merekam aktivitas tersebut. Digunakannya sèsèkan sebagai salah satu sarana mengekspresikan apa yang ada dalam kehidupan masyarakat Sasak telah membuktikan pentingnya sèsèkan bagi masyarakat Sasak itu sendiri.

\section{4) Pucuk Rêbung, Antap ljo, dan Kêléntang}

Kain pucuk rêbung terinspirasi dari tumbuhan bambu muda karena ornamennya menyerupai tunas bambu muda pada bagian bawah kain. Pucuk artinya 'ujung' dan rebung artinya 'tunas 
bambu muda'. Selain berfungsi sebagai seseren dan poposan, pada masa lampau pucuk rêbung sehari-hari juga dikenakan oleh para petani saat musim bercocok tanam. Masa munculnya pucuk rêbung merupakan pertanda waktu bercocok tanam yang baik. Mulai tumbuhnya pucuk rêbung merupakan pertanda bahwa musim hujan telah datang dan pada sasat itulah musim bercocok tanam yang baik untuk dilakukan. Oleh karean itulah, kain ini dinamai pucuk rêbung. Pucuk rêbung juga diolah dan dikonsumsi sebagai sayur yang disajikan dengan nasi dan lauk-pauk.

Sementara itu, antap ijo (bahasa Indonesia: kacang panjang) dan kêléntang (bahasa Indonesia: buah kelor) merupakan jenis sayuran yang ditanam oleh masyarakat Sasak. Antap ijo sering ditanam di pematang sawah bersamaan dengan komak, sedangkan kêléntang merupakan buah dari tanaman kelor. Masyarakat Sasak mengonsumsi kelor dan buahnya sebagai sayur. Antap ijo, komak, dan kêléntang sering dimasak menjadi makanan sederhana yang sangat digemari di Lombok. Masakan ini disebut kêlaq sia, kêlaq sia antap jika bahannya menggunakan antap ijo, kêlaq sia komakjika bahannya menggunakan komak dan kelak siang kêléntang jika bahannya menggunakan kêléntang. Dalam bahasa Indonesia, kata kêlaq berarti 'masak' dan kata sia berarti 'garam', jadi kêlaq siaq berarti 'masak garam'. Masakan ini memang berupa rebusan sayur antap ijo, komak, dan kêléntang yang ditambahkan garam serta sedikit buah asam. Masyarakat Sasak suka mengonsumi masakan ini ketika makan siang. Air rebusan sayur-sayuran ini dipercaya dapat menambah stamina sehingga ketika bekerja masyarakat Sasak tidak mudah merasa lelah. Para pekerja yang mengandalkan banyak tenaga, seperti tukang bangunan, petani, dan nelayan senang mengonsumsi masakan ini. Saat berpuasa, masakan ini juga sering dikonsumsi untuk sahur. Jadi, dengan mengonsumsi kêlaq sia stamina selama berpuasa tetap terjaga dan orang-orang dapat beraktivitas seperti hari-hari biasa ketika tidak berpuasa.

\section{Penanda Kepemilikan}

Ragi sêmpéda dan ragi montor merupakan kain yang dinamai karena pada zaman dahulu kain ini sering digunakan oleh laki-laki ketika naik sepeda atau motor. Menaiki sepeda atau sepeda motor pada zaman dahulu adalah hal yang tidak biasa di Lombok, masyarakat Sasak cukup memerhatikan orang-orang yang menaiki sepeda dan sepeda motor, alih-alih memerhatikan sepeda atau sepeda motor yang dikendarai, justru yang lebih diperhatikan adalah pakaian yang dikenakan oleh pengendaranya. Hal ini dapat menunjukkan bahwa masyarakat Sasak memerhatikan bagaimana seseorang berpenampilan. Di dalam masyarakat Sasak, penampilan memang sangat penting, menyesuaikan penampilan dengan berbagai kegiatan kemasyarakatan harus dilakukan di Lombok. Jika tidak melakukan hal tersebut, seseorang dapat dikucilkan dan dinilai tidak memiliki sopan-santun dalam bermasyarakat. Hal ini juga 
didukung dengan adanya kain ragi gênêp. Ragi gênêp berfungsi sebagai kain perlengkapan upacara. Gênêp yang berarti 'genap' menunjukkan makna kesempurnaan. Ketika melaksanakan upacara, masyarakat Sasak memakai ragi gênêp sebagai simbol kesungguhan hati terhadap sesuatu yang dilakukan pada saat upacara tersebut.

\section{Penanda Status Sosial}

\section{1) Londong Béak}

Ada dua jenis londong béak, yaitu londong beak yang memiliki rumbai dan tidak memiliki rumbai. Rumbai merupakan penanda jenis kelamin pemakainya. Londong béak berumbai digunakan oleh laki-laki dan londong béak tidak berumbai digunakan oleh perempuan. Apabila seseorang menggunakan londong béak maka orang tersebut dipastikan sebagai keturunan raja atau bangsawan. Londong béak juga digunakan oleh pemangku adat perempuan dan laki-laki di Bayan. Pemangku adat di Bayan merupakan keluarga kerajaan atau keturunan bangsawan. Ketika dalam upacara nyunatang, kain ini juga digunakan oleh laki-laki dan perempuan yang bertugas sebagai pemangku adat atau pimpinan desa.

\section{2) Payung Agung}

Motif payung sekaligus menjadi nama sèsèkan tersebut. Kata payung memiliki referen yang sama dalam bahasa Indonesia, yaitu 'payung', sementara kata agung berarti 'kebesaran'. Payung agung merupakan payung kebesaran dan lambang kekuasaan. Payung agung diibaratkan seperti langit yang menaungi Bumi. Di Lombok, tidak semua orang dapat dipayungi. Pada zaman dahulu, hanya raja yang boleh dipayungi. Payung agung merepresentasikan pemikiran masyarakat Sasak bahwa manusia selalu dilindungi, artinya dipayungi oleh Tuhan Yang Mahakuasa. Para raja sekaligus pemimpin merupakan wakil dari Tuhan untuk menjaga rakyat. Oleh karena itu, sebagai wakil Tuhan, para raja sekaligus pem impin harus dipayungi. Adanya pemahaman tersebut merepresentasikan bagaimana sèsèkan menjadi sangat penting dalam kehidupan masyarakat Sasak dalam menyimpan berbagai peristiwa sehari-hari.

\section{3) Taman Rêngganis}

Kain ini terinspirasi dari kisah seorang perempuan cantik di Pulau Lombok yang bernama Dewi Rengganis yang sangat menyukai bunga-bunga. Motif hias bunga dan burung merak pada kain ini merupakan simbol kelembutan dan kasih sayang. Sementara itu, motif hias sulur batang merupakan simbol kedamaian dan motif geometris berupa garis-garis lurus yang disusun miring membentuk garis zig-zag merupakan lambang keteraturan. Kisah-kisah menak seperti cerita Dewi Rengganis banyak diminati di Lombok, baik dari kalangan rakyat kecil maupun kalangan pembesar pada masanya. Dewi Rengganis merupakan cerita yang 
berkembang di antara bangsawan Sasak. Kain ini pun muncul di antara kalangan bangsawan. Kemunculannya juga sebagai songket. Oleh karena itu, kain ini dikenal dan digunakan oleh bangsawan atau masyarakat dengan kelas sosial tinggi.

\section{Penanda Religiusitas}

\section{1) Subahnalê}

Subahnalê berasal dari bahasa Arab subhanallah 'mahasuci allah'. Kalimat pujian terhadap Tuhan inilah yang diucapkan oleh seorang penenun masa lalu saat ia dapat menyelesaikan selembar kain tenun dan kain yang dihasilkannya disebut subahnalê. Dari subahanallah menjadi subahnalê merupakan penyerapan yang disesuaikan dengan pelafalan masyarakat Sasak. Kata subhanallah lazimnya diucapkan oleh orang-orang dengan latar belakang agama Islam. Adanya penggunaan istilah bahasa Arab yang mengarah kepada kepercayaan dalam agama Islam mencerminkan keadaan masyarakat Sasak yang mayoritas penduduknya memeluk agama Islam. Fakta ini sejalan dengan sebuah julukan yang diberikan kepada pulau Lombok, yaitu pulau seribu masjid. Julukan ini berdasar pada banyaknya bangunan masjid yang didirikan di Lombok oleh masyarakat Sasak yang memeluk agama Islam. Kain ini biasanya digunakan oleh kaum pria dan wanita untuk ibadah atau upacara adat. Selain itu, inti dari kain ini adalah motif segi enam seperti sarang lebah yang harus ada dalam setiap jenis subahnalê. Motif hias segienam merupakan simbol keyakinan umat muslim pada enam rukun iman, keikhlasan, dan berserah diri kepada Tuhan Yang Maha Esa.

\section{2) Pêsujudan}

Pêsujudan berarti 'tempat sujud'. Kain pêsujudan digunakan oleh masyarakat Sasak sebagai alas untuk salat (sajadah). Pêsujudan merupakan nama yang diambil dari salah satu istilah dalam gerakan salat. Adanya kain pêsujudan yang khusus dibuat untuk kegiatan salat menunjukkan pula agama yang dianut oleh masyarakat Sasak. Adanya leksikon nama sèsèkan yang diambil dari bidang agama menunjukkan sèsèkan juga dimanfaatkan sebagai alat penyimpan kepercayaan oleh masyarakat Sasak. Hal ini juga menunjukkan bahwa sèsèkan tidak hanya digunakan sebagai benda pakai yang melekat di tubuh, tetapi juga untuk alat lain yang berkaitan dengan kehidupan sehari-hari. Leksikon nama sèsèkan yang merambah bidang religiusitas ini memperkuat gambaran dirinya dalam masyarakat Sasak. Sejalan dengan apa yang disampaikan Duranti bahwa kata-kata dalam keberadaannya tidak pernah netral, selalu ada budaya yang melatarbelakangi keberadaannya.

\section{Penanda Gender}

\section{1) Sisok Mêl}

Sisok mêl merupakan kain yang dipakai hanya oleh laki-laki. Sisok mêl adalah metafora yang digunakan untuk menyebut alat kelamin laki-laki. Dalam bahasa Indonesai, kata sisok berarti 
'siput' dan mêl berarti 'sejuk'. Sisok merupakan penggambaran dari alat kelamin laki-laki dan mêl merupakan efek yang ditimbulkan oleh kain sisok mêl saat dikenakan. Kain ini digunakan oleh anak laki-laki yang baru disunat. Sifat dari bahan kain ini yang dingin dan sejuk ketika dipakai dapat mengurangi rasa sakit yang dirasakan oleh anak laki-laki selama luka sunatnya belum sembuh. Bahan dari kain juga khusus dibuat lebih lembut dari bahan sèsèkan yang lain. Tujuannya, jika luka sunat tidak sengaja tersentuh oleh kain ini maka tidak akan menimbulkan rasa sakit yang berlebihan. Anak laki-laki dalam masa penyembuhan luka sunat juga dipercaya tidak akan cerewet dan banyak mengeluh sakit jika dipakaikan kain ini sehingga orang tua merasa lebih tenang menghadapi anaknya yang sedang masa penyembuhan.

\section{2) Pancor Boros}

Pancor boros hanya dipakai oleh perempuan. Sama halnya dengan sisok mêl, kain pancor boros merupakan metafora dari alat kelamin perempuan. Dalam bahasa Indonesia, kata pancor berarti 'pancuran' dan boros berarti 'bocor'. Kain ini berbentuk sabuk dengan panjang 5-9 meter. Nama pancor boros digunakan sebagai analogi perempuan yang baru saja melahirkan dan dalam masa nifas. Kain ini digunakan sebagai ikat pinggang penyangga perut perempuan. Hal ini bertujuan untuk meminimalisir pergerakan pada rahim perempuan yang masih rentan ketika baru saja selesai melahirkan. Pemakaian pancor boros juga dapat membantu perempuan untuk bergerak lebih bebas dan mengurangi rasa sakit sehabis melahirkan.

Kain pancor boros menggambarkan masyarakat Sasak dalam menangani masalah persalinan. Pengembalian kondisi vagina yang melebar setelah melahirkan menjadi seperti semula merupakan hal yang penting bagi masyarakat Sasak. Hal tersebut untuk menjaga kepuasan berhubungan intim dari pihak suami. Keadaan ini juga memberi gambaran tentang masyarakat Sasak dalam memperlakukan laki-laki. Sebagai masyarakat patriarkal, memberikan pelayanan yang baik terhadap laki-laki merupakan suatu keharusan dalam masyarakat Sasak.

\section{b. Perlengkapan Upacara}

Dalam kehidupannya, masyarakat Sasak mengenal berbagai macam upacara. Upacara tersebut, misalnya upacara pernikahan yang meliputi upacara sorong serah aji krama dan nyongkolan, dan upacara kematian (upacara betukak). Upacara-upacara tersebut merupakan upacara yang rutin dilakukan oleh masyarakat Sasak dan keberadaan sèsèkan merupakan bagian yang tidak dapat dipisahkan dalam upacara-upacara itu. Namun, tidak semua sèsèkan memiliki peranan yang sama. Dalam konteks ini akan dibahas sèsèkan yang memiliki peranan yang cukup penting dalam masyarakat Sasak. 
Upacara Pernikahan

Ada dua rangkaian upacara pernikahan dalam masyarakat Sasak yang melibatkan sèsèkan sebagai perlengkapan upacara. Upacara tersebut adalah upacara sorong serah aji krama (SSAK) dan upacara nyongkolan. Upacara SSAK dan nyongkolan merupakan rangkaian upacara adat pernikahan yang dilakukan masyarakat Sasak. SSAK dilaksanakan sebelum janji pernikahan diikrarkan dan nyongkolan merupakan rangkaian acara yang dilakukan setelah janji pernikahan diikrarkan. Keabsahan suatu pernikahan dalam tradisi masyarakat Sasak direfleksikan dalam tradisi SSAK. Upacara SSAK dilakukan dengan penyerahan benda-benda sebagai simbol nilai dalam adat-istiadat Sasak oleh pêmbayun pênyorong yang mewakili pihak mempelai laki-laki kepada pêmbayun pênampi yang mewakili pihak mempelai perempuan. Dalam upacara ini, sèsèkan juga memiliki peranan yang tidak dapat dipisahkan. Dalam penelitian ini, sèsèkan yang berkaitan dengan upacara pernikahan, yaitu umbaq dan bintang êmpêt.

\section{1) Umbaq}

Kain umbaq digunakan dalam rangakaian SSAK. Jenis umbaq yang digunakan pada upacara SSAK adalah umbaq yang pada rumbainya terdapat ikatan uang logam bolong. Di Setanggor, umbaq ini biasanya disebut umbaq batu sedangkan di Sembalun umbaq ini disebut sebagai umbaq ragi majapahit (Rahayu, dkk., 2002:17). Umbaq batu merupakan kain umbaq seorang anak laki-laki atau perempuan yang telah menikah dan tidak memiliki keturunan atau anak yang telah dibuatkan umbaq, tetapi meninggal saat berusia remaja sebelum memiliki keturunan maka kain umbaq milik mereka diikatkan uang logam bolong. Oleh karena itu, umbaq ini disebut sebagai umbaq batu. Umbaq batu digunakan sebagai olen-olen pada saat SSAK. Umbaq batu dapat dipinjamkan kepada keluarga yang membutuhkan, dahulu keluarga yang meminjam umbaq batu harus menambah ikatan uang logam bolong (Rahayu, dkk., 2002:17)

\section{2) Bintang Êmpêt}

Bintang empet artinya bintang yang bertaburan di langit. Motif hias bintang empet sebagai simbol ketuhanan dan ilmu perbintangan (astronomi). Istilah bintang êmpêt berhubungan dengan arah mata angin yang diambil sebagai inspirasi keluarnya bintang timur pada pagi hari yang menandakan fajar segera tiba. Motif bintang êmpêt juga menceritakan tentang penanggalan zaman nenek moyang masyarakat Sasak untuk mengetahui musim hujan dan musim panas. Sementara itu, kain bintang êmpêt matahari hanya berupa variasi dari kain bintang êmpêt. Kain bintang êmpêt, bintang êmpêt matahari, dan ragi gênêp merupakan pasangan kain yang harus dipersiapkan bagi perempuan yang mau menikah untuk dibawa sebagai hadiah calon suami. Bagi masyarakat Sasak, mengetahui musim panas dan musim 
hujan sangatlah penting. Hal ini karena masyarakat Sasak memiliki tradisi mengadakan upacara pernikahan ketika musim panas tiba, yaitu saat dan pascamusim panen padi. Oleh karena itu, kain bintang empat dipergunakan sebagai salah satu syarat dalam pernikahan masyarakat Sasak.

\section{Upacara Kematian}

Upacara kematian masyarakat Sasak disebut belangar atau betukak. Betukak diawali dengan kunjungan dari sanak saudara, tetangga, dan kerabat kepada anggota keluarga orang yang meninggal dunia. Upacara betukak dilakukan berdasarkan aturan agama Islam. Sebelum dikuburkan, orang yang meninggal dimandikan terlebih dahulu, disalatkan, dan dimakamkan. Upacara betukak menggunakan beberapa sèsèkan sebagai kelengkapan upacara. Sèsèkan tersebut, yaitu bêbasaq, sêlulut, dan tapo kêmalo.

\section{1) Bêbasaq}

Kata bêbasaq berarti 'basahan'. Dalam masyarakat Sasak bêbasaq memiliki makna ketulusan, kesucian, dan keikhlasan hati. Pada zaman dahulu, kain ini digunakan sebagai kain pembungkus jasad orang yang meninggal ketika dimandikan. Namun, seiring perkembangan zaman kain ini juga digunakan sebagai benda yang diserahkan pada tradisi nyelabar, yaitu tradisi memberi tahukan kepada pihak keluarga perempuan dari pihak keluarga laki-laki bahwa anaknya diculik untuk dinikahkan.

\section{2) Sêlulut}

Kata sêlulut atau selolot berasal dari kata selolok yang berarti 'perjalanan' memiliki motif garis berwarna hijau yang melambangkan kesejukan, kain ini digunakan untuk alas pada jasad, mereka percaya bahwa kain selolot akan memberikan rasa sejuk dan nyaman kepada seseorang yang meninggal tersebut. Sebagai mayoritas pemeluk agama Islam, masyarakat Sasak mempercayai adanya kehidupan setelah kematian. Seseorang yang meninggal dunia akan menghadapi perjalan kehidupan selanjutnya. Oleh karena itu, kain ini digunakan pada jasad sebagai simbol untuk mengantar arwah orang yang meninggal menuju perjalan kehidupan yang selanjutnya. Warna hijau dan putih pada warna sêlulut merupakan perwujudan warna yang disukai oleh Nabi Muhammad. Dengan kedua warna ini, diharapkan jiwa orang yang meninggal tersebut dapat bertemu dengan Nabi Muhammad.

\section{3) Tapo Kêmalo}

Kain tapo kemalo digunakan saat upacara kematian pada proses naletang 'memakamkan' orang yang meninggal dunia. Kain tapo kêmalo memiliki warna dasar hitam dengan garis putih memenuhi bidang kain. Pada bagian pinggir dan sedikit di tengah bidang kain terdapat warna merah. Warna merah inilah yang disebut dengan tapo. Tapo merupakan penanda 
bagian luar dan bagian dalam kain. Kain ini tidak boleh digunakan terbalik karena mewakili pemakainya untuk menyampaikan rasa simpati kepada orang lain. Kain ini biasanya juga dipadukan dengan kain lain yang disebut kelungkung sebagai ikat pinggang.

\section{c. Benda Magis}

Sèsèkan yang menjadi benda magis dalam penelitian ini hanya satu. Kain tersebut adalah kain umbaq. Sebagai benda penting dalam upacara-upacara, umbaq dipercaya memiliki kekuatan magis sehingga dalam pembuatannya harus memenuhi syarat-syarat dan proses tertentu. Misalnya, pada proses ngane benang, umbaq hanya boleh dilakukan pada hari Rabu dan Sabtu. Penyelesaian proses tenun juga harus jatuh pada hari yang sama. Penenun harus perempuan yang sedang tidak menstruasi dan pelaksanaannya diiringi dengan ritual bêgawe umbaq.

Di Desa Pujut, Lombok Tengah umbaq dinamai dengan nama-nama para leluhur yang membawa Islam ke Lombok sebagai bentuk penghormatan (Rahayu, dkk., 2002:27). Namanama tersebut, yaitu umbaq pujut, umbaq dapur, umbaq saleh, umbaq batu dendeng, dan umbaq jomang. Selain itu, sebagai benda magis, umbaq tidaklah sendiri, tetapi dilengkapi dengan dua sèsèkan lain, yaitu katik dan belat. Kedua kain ini merupakan kain pelengkap yang disandingkan dengan umbaq. Katik merupakan kain kecil yang biasa digunakan masyarakat Sasak di Lombok Tengah untuk menutup kepala anak kecil ketika diajak keluar rumah. Tujuannya agar anak tersebut tidak kepanasan dan dan tidak kêtêmuk, istilah yang digunakan apabila anak-anak terkena gangguan jin atau nenek moyang yang sudah meninggal dan berusaha berinteraksi dengan cucunya. Sementara itu, belat tidak hanya digunakan sebagai kelengkapan upacara dengan umbaq, juga digunakan sebagai sabuk perang karena benda ini sangat diyakini memiliki kekuatan magis.

Seiring perkembangan zaman, sèsèkan juga mengalami banyak inovasi, terutama dalam fungsinya. Pada zaman dahulu pemakaian sèsèkan sangat mematuhi aturan-aturan yang berlaku di masyarakat, misalnya payung agung dan subahnale. Kain ini hanya boleh digunakan oleh raja, keluarga raja, bangsawan, dan keturunannya. Namun, pada masa sekarang kain tersebut dapat digunakan oleh semua kalangan. Kain payung agung, misalnya, digunakan oleh pasangan yang menikah dari latar belakang kelas sosial mana pun. Begitu pula halnya dengan subahnalê, pada zaman dahulu kain ini digunakan untuk beribadah. Akan tetapi, pada masa sekarang subahnalê digunakan oleh semua kalangan, biasanya oleh keluarga orang yang mengadakan pesta pernikahan adat sasak atau sebagai seragam para pegiat budaya tradisional sasak, misalnya komunitas gêndang bêleq. 
Pergerseran fungsi ini memang tidak dapat dihindari karena zaman berkembang seiring perkembangan manusia. Hal ini didorong oleh sikap untuk selalu menyertai peristiwa penting yang berkaitan dengan daur hidup (Herman, 1991:78). Peristiwa penting dalam daur hidup meliputi perkembangan pola pikir. Perkembangan pola pikir juga dapat mengubah cara pandang masyarakat terhadap benda-benda di sekitarnya. Penciptaan yang dilakukan masyarakat Sasak terhadap sèsèkan menggambarkan perpaduan antara konsep lama dan konsep baru. Konsep lama dan konsep baru dapat menyatu karena konsepsi-konsepsi dalam nilai-nilai kehidupan yang lama tidak bisa hilang begitu saja berganti yang baru.

\section{SIMPULAN}

Berdasarkan uraian di atas, sèsèkan memiliki hubungan yang erat dengan kehidupan masyarakat. Hal ini terbukti dari aspek penyebutan leksikon-leksikon kain tenun yang sangat mendetail sesuai fungsi dan makna yang terkandung dalam setiap jenis sèsèkan tersebut. Penamaan tertentu pada sèsèkan mempunyai makna tersendiri karena berkaitan erat dengan hal-hal di sekitar lingkungan masyarakat Sasak. Leksikon-leksikon pada sèsèkan yang memberi gambaran tentang kehidupan sosial, agama, dan budaya masyarakat Sasak. Dari penjelasan tersebut dapat ditarik garis besar bahwa leksikon sèsèkan dalam pandangan masyarakat Sasak memiliki fungsi budaya, fungsi keagamaan, dan fungsi sosial.

Leksikon-leksikon dalam Sèsèkan tidak terbatas pada leksikon-leksikon yang diuraikan oleh peneliti. Masih terdapat banyak leksikon-leksikon Sèsèkan yang belum ditelaah secara mendalam, seperti tapo kemalo, cabuk bendang, kelungkung, berang, dan tuntang balik, dan lainlain. Dalam penelitian ini, peneliti mengakui masih banyak kekurangan-kekurangan yang harus dilengkapi. Oleh karena itu, peneliti berharap dapat menyempurnakan penelitian ini di lain kesempatan.

\section{DAFTAR PUSTAKA}

Fatehah, Nur. "Leksikon Perbatikan di Pekalongan (Kajian Etnolinguistik)", Tesis, Fakultas Ilmu Budaya, Universitas Gadjah Mada, Yogyakarta, 2008.

Duranti, Alessandro. 1997. Linguistic Anthropology. United States: Cambridge University Press.

Herman, V.J. 1991. Ragam Hias pada Kain Tenun Nusa Tenggara Barat. Jakarta: Departemen Pendidikan dan Kebudayaan Direktorat Jenderal Kebudayaan Museum Nusa Tenggara Barat.

http://novikhairi.blogspot.co.id/2016/01/filsafat-k3-tenun-songket-sukarara.html.

Kridalaksana, Harimurti. 2008. Kamus Linguistik. Jakarta: PT Gramedia.

Koenjtaraningrat. 2000. Pengantar Antropologi I. Jakarta: Rineka Cipta 
Nurmeisarah, Trisna, dkk. "Tinjauan Tentang Tenun Tradisional Dusun Sade Desa Rambitan Kecamatan Pujut Kabupaten Lombok Tengah", makalah, Universitas Pendidikan Ganesha, Bali, 2015.

Rahayu, Dewi Dwi, dkk., 2002. Lempot Kombong Umbaq sebagai Benda Upacara Adat di Lombok. Lombok: Museum Negeri Nusa Tenggara Barat.

Santoso, Joko. 2006. Semantik. Yogyakarta: UNY Press.

Sari, Chyndy Febrinda. "Leksikon Hantu dalam Bahasa Indonesia (Sebuah Tinjauan Linguistik Antropologis)", Tesis, Fakultas IImu Budaya, Universitas Gadjah Mada, Yogyakarta, 2015 .

Sibarani, Robert. 2004. Antropolinguistik: Antropologi Linguistik, Linguistik Antropologi. Medan: Penerbit Poda.

Suhandano. "Klasifikasi Tumbuh-Tumbuhan dalam Bahasa Jawa (Sebuah Kajian Linguistik Antropologis)", Disertasi, Fakultas Ilmu Budaya, Universitas Gadjah Mada, Yogyakarta, 2004 .

Widhiarso, Wahyu. 2005. "Pengaruh Bahasa terhadap Pikiran: Kajian Hipotesis Benyamin Whorf dan Edward Sapir". Tidak diterbitkan. Yogyakarta: Fakultas Psikologi Universitas Gadjah Mada.

Wierzbicka, Anna. 1997. Understanding Cultures through Their Key Words. New York: Oxford University Press. 